\title{
TRANSLATION TECHNIQUE AND THEOLOGY IN THE SEPTUAGINT OF AMOS ${ }^{1}$
}

\author{
W. Edward Glenny
}

The goal of this dissertation is to describe and analyse as exhaustively as possible the translation technique and exegetical practice of the translator of the Septuagint of Amos. Two other works were especially influential on this study. Jennifer Dines had already done exegetical spadework in LXX-Amos, which was built upon in this work, and James Palmer's study of translation technique in LXX-Zechariah provided a methodology that could be applied to another of the LXXTwelve to compare the translation technique in LXX-Amos with Palmer's conclusions concerning LXX-Zechariah. ${ }^{2}$ The contributions of the present dissertation were possible because it builds on these previous works.

The focus of this study is the differences between the MT and Ziegler's (Göttingen) LXX text in Amos, which are the main indicators of the translator's translation technique and theology. LXX-Amos is fairly close to the MT, as are the rest of the LXX-Twelve, but there are still many differences between the two traditions. There are several possible reasons for the differences between the LXX and the MT. They could be the result of a different Vorlage, a mistranslation or misreading of the Hebrew or Greek texts, exegesis, or the translator's translation technique.

The dissertation is divided into two main parts addressing in order the translation technique (chapters 2-4) and the theology (chapters 5-

\footnotetext{
1 Ph.D. dissertation, University of Minnesota, 2007. Supervisor: Dr Philip H. Sellew. This dissertation was published as Finding Meaning in the Text: Translation Technique and Theology in the Septuagint of Amos (VTSup 126; Leiden: Brill, 2009). For a summary of the evidence in this dissertation concerning translation technique and theology in LXX-Amos, see W. Edward Glenny, 'Hebrew Misreadings or Free Translation in the Septuagint of Amos?' VT 57:4 (2007): 524-47.

2 Jennifer Mary Dines, 'The Septuagint of Amos: A Study in Interpretation' (Ph.D. dissertation, London, 1991) and James Karol Palmer, "Not Made with Tracing Paper:" Studies in the Septuagint of Zechariah' (Ph.D. dissertation, Cambridge, 2004).
} 
7) of LXX-Amos. Chapter two is an application to LXX-Amos of categories of literalism developed by Barr and Tov. The evidence supports the consensus of opinion that the LXX translation of Amos is fairly literal, especially in word order; however, the translator was not concerned about representing the constituent elements in his source text by their individual equivalents (segmentation) or stereotyping word equivalents. Chapter three ('The Translation of Difficult and Unknown Words') focuses on six types of conjectural renderings that Tov suggests may be recognised in the LXX: (1) untranslated words (transliterations); (2) contextual guesses; (3) contextual manipulation; (4) reliance on parallelism; (5) employment of general words; and (6) etymological guesses. Examples of all six are found in LXX-Amos. These six categories are not mutually exclusive, and it appears that the translator was not always conscious he was employing such methods when he encountered words he did not know. The evidence in this chapter suggests that the translator rendered his text freely, or was open to manipulate the Vorlage when it did not make sense to him, in order to make sense of it; it also suggests he used a text very similar to the MT. Also, the results of this chapter are very similar to other studies of translation technique in the Minor Prophets, especially by Palmer and Muraoka, and support the theory that there was one translator of the Minor Prophets. Chapter four ('Visually Ambiguous Phenomena') deals with the rendering of visually ambiguous phenomena, specifically homonyms, homographs, and word divisions in LXXAmos. Often the translator did not understand such visually ambiguous phenomena, and awareness of his renderings of such patterns is necessary to understand the translation technique employed in LXXAmos and to make decisions about the translator's Vorlage. Often what appears to happen is that the translator encounters a problem or obscurity in his Vorlage and uses visually ambiguous phenomena in the text to attempt to understand the text. In such passages where divergences in LXX-Amos from the MT tend to follow upon each other it appears that vocalisation of the text did not precede the translator's rendering of it, but instead his decisions concerning the meaning led to his choice of the vocalisation of the ambiguities. This chapter further confirms that the Vorlage of the translator of LXXAmos could have been very close to the MT.

Normally it is in the difficult or obscure sections of the Vorlage that the translator's theological biases also appear, and Part Two of the 
dissertation addresses the theology of LXX-Amos. Three areas of theological bias or Tendenz are especially important in LXX-Amos; they are anti-Syrian and anti-Samaritan bias (chapter five), the doctrine of God (chapter six), and finally Gentiles, eschatology, and messianism (chapter seven). Because the translator of LXX-Amos follows closely his Vorlage, and develops his own ideas and concerns primarily where he finds difficulties in the Hebrew text, it is natural that his theology follows fairly closely the emphases in the Hebrew text of Amos; thus the anti-Syrian and anti-Samaritan bias in LXX-Amos are a further development of main themes in all versions of Amos. Such bias is found in the LXX renderings in $1: 3-5,15 ; 3: 12 ; 4: 2,3,5 ; 6: 1,7 ; 8: 14$; and 9:7. There is also evidence of anti-Baal polemic in 1:4 and 4:13 and Hellenistic religious influences in 2:4, 8; and 7:9. Chapter six ('God in LXX-Amos') contains a discussion of reverential renderings of God, the treatment and use of anthropomorphisms, and the use of Pantokrator in LXX-Amos. The translator is concerned about descriptions of God that might compromise God's character (esp. 4:4, 5 and 8:7), but with the exception of 1:2, he does not seem to be bothered by anthropomorphic descriptions of God. The use of Pantokrator to render Sabbaoth is consistent with the translation technique throughout the Minor Prophets and argues for one translator of LXX-Twelve; additions of Pantokrator (3 times) in Amos indicate that changing concepts of God among the Jews had influenced the translator, and he saw God more as a universal sovereign, which has implications for the relationship of Gentiles to God. Chapter seven brings together three topics that are related in LXX-Amos; it addresses 'Gentiles, Eschatology, and Messianism in LXX-Amos'. Differences between the MT and the LXX in LXX-Amos give several hints of the importance of these topics to the translator of LXX-Amos. Key eschatological passages are $4: 2 b ; 7: 1 ; 8: 8,14 ; 9: 5$; and 9:9-10. LXX-Amos 9:11-12 is a very important passage in the development of Christian theology (esp. Acts 15:16-17), because of its description of Gentiles seeking the Lord (object implied in LXX) and being his people (having his name called upon them). LXX-Amos 4:13 and 9:11-12 also connect Gentiles with Messianic ideas. The rendering of LXX-Amos suggests that there was an expectation in the community of the translator of an eschatological, messianic, saviour $(4: 13 ; 9: 11)$, who would open the way for Gentiles to seek the Lord (4:13; 9:12), and that there would also be an appearance of his eschatological enemy, Gog (7:1). 
A final chapter considers the translator of LXX-Amos. It is argued that he was more of a scholar-scribe than a dragoman; he was skilled at exegeting his text and using parallels to interpret it. He probably had a general knowledge of Hebrew, but he was not an expert in it. He also probably made the translation in Egypt in the mid Second Century BC, and the evidence from LXX-Amos suggests he was also the translator of the other Minor Prophets. Although he is free to contemporise his translation, the contemporising is not so programmatic that it should be called 'fulfilment-interpretation'. The evidence throughout indicates that the Vorlage of LXX-Amos was a Hebrew text very similar to the MT. 